\title{
TINDAK TUTUR ILOKUSI DALAM NOVEL GURU AINI KARYA ANDREA HIRATA
}

\author{
Yuyun $^{1 *}$, Patriantoro ${ }^{2}$ \\ yuyun21@student.untan.ac.id ${ }^{1 *}$,patriantoro@fkip.untan.ac.id ${ }^{2}$ \\ Universitas Tanjungpura Pontianak, Indonesia ${ }^{1,2}$
}

\begin{abstract}
ABSTRAK
Masalah yang dibahas dalam penelitian adalah bentuk-bentuk tindak tutur ilokusi yang meliputi asertif, direktif, ekspresif, komisif, dan deklarasi dalam novel Guru Aini Karya Andrea Hirata serta implementasi dalam pembelajaran di sekolah, dengan tujuan untuk mendeskripsikan masalah tersebut. Metode yang digunakan dalam penelitian ini adalah metode deskriptif. Bentuk dalam penelitian ini merupakan bentuk kualitatif. Teknik pengumpulan data yang digunakan dalam penelitian ini adalah teknik studi dokumenter yaitu membaca isi keseluruhan isi novel, mengidentifikasi, menandai, mengklasifikasikan dan memasukkan ke kartu data teknik menguji keabsahan data yaitu ketekunan pengamatan dan kecukupan referensial. Berdasarkan hasil analisis, tindak tutur ilokusi direktif adalah paling dominan dalam novel Guru Aini karya Andrea Hirata. Implementasi pembelajaran dalam penelitian ini terdapat pada jenjang SMP kelas VIII semester genap pada Kompetensi Dasar pengetahuan 3.14 Menelaah struktur dan kebahasaan teks persuasi, 4.14 Menyajikan teks persuasi secara tulis dan lisan dengan memperhatikan struktur, kebahasaan, atau aspek lisan.
\end{abstract}

Kata-kata kunci: tindak tutur ilokusi; novel Guru Aini; pembelajaran Bahasa Indonesia

\section{ILOCUSION SPEECH IN NOVEL GURU AINI BY ANDREA HIRATA}

\begin{abstract}
The researcher chose ilocutionary speech act as the main focus of tehe research, because it was a speech that was often encountered in eeverday life. The issue discussed in the research were the from of illocutionary speech acts included assertive, directive, expressive, commissive, and declarative in novel of Guru Aini by Andrea Hiarata. The method used in this research was descriptive method. The form was a qualitative form. The data source was novel of Guru Aini karya Andrea Hiarata, and the data sused was the form of the illocutionary speech acts. The technique of data collecting used in this research was a documentary study technique. The teachniques to test the validity of the data were observational persistence an referential adequacy. Based on the results of the analysis, the assertive speech acts was he most dominant in the novel of Guru Aini by Andrea Hirata. The Implementation of learning of SMP class VIII semester in Basic Competence 3.14 reviewing the structure and language persuasive texts, 4.14 presenting the persuasive texts in written and oral regarding to the structure, language, or oral aspects.
\end{abstract}

Key words: illocutionary speech acts; Guru Aini novels; Indonesian langguage learning. 


\section{PENGANTAR}

Bahasa merupakan peranan penting dalam kehidupan setiap manusia, karena bahasa digunakan sebagai alat berinteraksi dan berkomunikasi dengan orang lain. Bahasa adalah suatu kenyataan bahwa manusia menggunakan bahasa sebagai alat vital dalam kehidupan. Bahasa ialah alat komunikasi antar anggota masyarakat berupa simbol bunyi yang dihasilkan oleh alat ucap manusia.

Pragmatik sebagai telah mengenai makna tuturan (utterance) menggunakan makna yang terikat konteks. Memperlakukan bahasa secara pragmatik ialah memperlakukan bahasa dengan mempertimbangkan konteksnya, yakni penggunaannya pada peristiwa komunikasi. Tarigan (2009) Pragmatik (atau semantik behavioral) menelah ucapan-ucapan khusus dalam situasi khusus dan memusatkan perhatian pada aneka ragam cara yang merupakan wadah aneka konteks sosial. George (dalam Tarigan, 2009), Pragmatik (atau semantik behavioral) menelah keseluruhan perilaku insan, terutama dalam hubungannya dengan tanda-tanda dan lambang-lambang. Pragmatik memusatkan perhatian pada cara insan berperilaku dalam keseluruhan situasi pemberian dan pemberian tanda.

Tindak tutur bukanlah peristiwa yang terjadi dengan sendirinya melainkan sebagai wujud peristiwa komunikasi yang mempunyai fungsi, mengandung maksud dan tujuan tertentu, dan dapat menimbulkan pengaruh atau akibat pada mitra tutur. Rusminto (2015) menyatakan tindak ilokusi adalah tindak tutur yang mengandung daya untuk melakukan tindakan tertentu dalam hubungannya dalam melakukan sesuatu (an act of saying somethings). Tindak tutur ilokusi adalah tindak tutur yang berfungsi untuk menyatakan atau menginformasikan sesuatu dan dipergunakan untuk melakukan sesuatu tindakan. Di pihak lain, Searle (dalam Rusminto, 2015) mengklasifikasikan tindak ilokusi menjadi lima macam, (1) asertif (assertives), (2) direktif (directives), (3) komisif (commissives), (4) ekspresif (ekspressives), (5) deklaratif (declarattion). Berdasarkan bentuk-bentuk tindak tutur ilokusi menurut para ahli tersebut, penulis memilih teori Searle sebagai fokus penelitian tindak tutur ilokusi pada novel Guru Aini karya Andrea Hirata. Teori tersebut sekaligus menjadi masalah penelitian yang telah dibahas di bagian masalah penelitian.

Novel merupakan sebuah karya fiksi prosa yang ditulis dalam bentuk cerita. Karya sastra seperti novel mengandung permasalahan yang melingkupikehidupan manusia. Tindak tutur ilokusi dapat dilihat dalam novel karena mengandung alur cerita melalui dialog antartokoh. Dialog yang terdapat dalam novel merupakan bentuk tuturan yang diolah menjadi komunikasi sehari-hari. Hal itu dimaksudkan agar tuturan tersebut mudah dipahami oleh pembacanya. Selain itu, dialog antar tokoh juga membuktikan bahwa dalam novel terdapat penutur dan mitra tutur dalam sebuah peristiwa tutur. Berdasarkan ulasan tersebut, penulis ingin meneliti tuturan dalam novel yang di dalamnya terdapat tindak tutur dari tokoh-tokoh fiksi. Tindak tutur tersebut sepatutnya dikaji agar bentuk makna dan tuturan yang disampaikan mudah dipahami. Oleh karena itu, novel dapat dijadikan bahan kajian tindak tutur dalam penelitian ini.

Penulis memilih tindak tutur ilokusi sebagai objek penelitian dengan beberapa pertimbangan sebagai berikut. Pertama, belum ada penelitian yang dilakukan terhadap novel ini, khususnya penelitian tindak tutur. Kedua, menurut observasi awal terdapat beragam tuturan asertif, direktif, ekspresif, komisif, dan deklarasi yang 
ditemukan dalam novel Guru Aini sehingga menguatkan penelitian. Ketiga, watak tokoh yang beragam serta jalan cerita yang unik menunjukkan bahwa terdapat banyak peristiwa tutur, sehingga terdapat banyak penutur dan mitra tutur. Keempat, novel mengandung tuturan yang disampaikan oleh tokoh melalui dialog. Kelima, novel ini merupakan novel populer sehingga pada masa ini banyak penggemarnya, khususnya pembaca di kalangan remaja, dan memungkinkan pemanfaatan penelitian ini berdampak positif terhadap, siswa, pendidik, maupun penikmat karya sastra. Keenam, novel ini menyajikan sebuah cerita yang menarik karena pengarang mengangkat tema pendidikan dengan berlatarkan kehidupan sehari-hari selain itu Bahasa yang digunakan mudah dibaca sehingga dapat dipahami. Ketujuh, novel ini tergolong karya terbaru yang ditulis oleh Andrea Hirata, sehingga penelitian ini menjadi penambahan dan pelengkap untuk penelitian sebelumnya. Berdasarkan penjelasan tersebut penulis memilih novel Guru Aini karya Andrea Hirata. Novel ini terbit pada tahun 2020. Novel Guru Aini adalah karya terbaru Andrea Hirata yang merupakan prekuel dari karya sebelumnya yaitu novel Orang-Orang Biasa.

Berdasarkan hasil penelusuran yang dilakukan oleh penulis, baik di Fakultas Keguruan dan Imu Pendidikan Universitas Tanjungpura maupun di program studi Bahasa dan Sastra Indonesia serta di perguruan tinggi lainnya, penelitian mengenai tindak tutur ilokusi dalam novel Guru Aini karya Andrea Hirata belum pernah diteliti sebelumnya. Oleh sebab itu, penulis memutuskan untuk mengkaji nilai-nilai pendidikan karakter pada novel ini.

Dihubungkan dengan pendidikan penelitian ini dapat diimplementasikan pada Mata Pelajaran Bahasa Indonesia Kurikulum 2013 jenjang Sekolah Menengah Pertama (SMP) kelas VIII semester genap dengan Kompetensi Dasar (KD) 3.14 "Menelah struktur dan kebahasaan teks persuasi yang berupa saran, ajakan, arahan, dan pertimbangan tentang berbagai permasalahan aktual." Kompetensi Dasar (KD) 4.14 "Menyajikan teks persuasi (saran, ajakan, arahan, dan pertimbangan) secara tulis dan lisan dengan memperhatikan struktur, kebahasaan atau aspek lisan.”

\section{KERANGKA TEORI DAN METODOLOGI}

Pragmatik adalah satu di antara cabang ilmu Bahasa yang masih tergolong baru bila dilihat dari perkembangannya. Menurut Wijana (1996) menyatakan bahwa semantik dan pragmatik adalah cabang-cabang ilmu Bahasa yang menelah makna-makna satuan lingual, hanya saja semantik mempelajari makna secara internal, sedangkan pragmatik mempelajari makna secara eksternal. Yule (2015) menyatakan, pragmatik adalah kajian makna "yang tidak terlihat," atau bagaimana kita mengetahui apa yag dimaksud bahkan ketika makna tersebut sebenarnya tidak dikatakan atau ditulis. Berdasarkan pendapat para ahli tersebut, dapat disimpulkan bahwa pragmatik adalah cabang ilmu Bahasa yang memperlakukan Bahasa dengan mempertimbangkan konteksnya, yakni penggunanya pada peristiwa komunikasi.

Tindak tutur adalah produk atau hasil dari suatu kaliamat dalam kondisi tertentu dan merupakan kesatuan terkecil dari komunikasi linguistik yang dapat berwujud pernyataan, pernyataan perintah atau yang lainnya. Menurut Chaer (2003) menyatakan bahwa, tindak tutur merupakan gejala individual, bersifat psikologis, dan keberlangsungannya ditentukan oleh kemampuan Bahasa si penutur dalam menghadapi situasi tertentu. Hal 
ini menunjukkan bahwa dalam peristiwa tutur (speech event) terdapat interaksi antara penutur dalam menghadapi situasi situasi dan tempat tertentu meskipun tindak tutur (speech acts) lebih cenderung sebagai gejala individual. Dell Hymes dalam (Rohmadi, 2011) ada beberapa syarat terjadinya peristiwa tutur yang terkenal dengan akronimnya SPEAKING. Syarat-syarat terjadinya peristiwa tutur itu adalah sebagai berikut.

a. S (setting and Scene) berkenan dengan waktu dan tempat tuturan berlangsung, sedangkan scene mengacu pada situasi tempat, dan waktu, atau situasi psikologis pembicaran.

b. $\mathrm{P}$ (participant) adalah pihak-pihak yang terlibat dalam pertuturan bisa pembicara dan pendengar, penyapa dan pesapa, atau pengirim dan penerima.

c. E (end) merupakan maksud dan tujuan pertuturan.

d. A (act Sequance) mengacu pada bentuk dan isi ujaran yang digunakan oleh penutur.

e. K (key) mengacu pada cara dan semangat seorang penutur dalam menyampaikan pesan. Apakah dengan sombong, rendah hati, angkuh atau dengan cara yang lain.

f. I (instrument) mengacu pada jalur Bahasa yang digunakan seperti Bahasa lisan, tertulis, dan isyarat.

g. $\mathrm{N}$ (norm) mengacu pada norma atau aturan dalam berinteraksi.

h. G (genre) mengacu pada bentuk penyampaian suatu pesan. Apakah dalam bentuk puisi, prosa, dan doa, (Hymes dalam Rohmadi, 2011).

Dari pendapat-pendapat tersebut dapat disimpulkan bahwa tindak tutur lebih dilihat pada makna atau arti tindakan dalam suatu tuturannya yang dilakukan melalui ujarannya yang sedang berlangsung sesuai dengan maksud yang diujarkan oleh penutur utama pada mitra bicara atau pendengar.

Konteks memiliki peranan yang penting dalam pragmatik, hal ini seperti definisi konteks yang diungkapkan oleh Leech (1983) mengungkapkan bahwa latar belakang pemahaman yang dimilikiii oleh penutur maupun lawan tutur, sehingga lawan tutur dapat membuat interpretasi mengenai apa yang dimaksud oleh penutur pada waktu membuat tuturan tertentu, dengan demikian konteks adalah hal-hal yang berkaitan dengan lingkungan fisik, lingkungan sosial sebuah tuturan, dan latar belakang sebuah pengetahuan yang sama-sama dimilikiii oleh penutur, dan lawan tutur, serta mendukung lawan tutur untuk memahami/memahami maksud tuturan, dan harus adanya syarat terjadinya tuturan satu dengan yang lain yang dikenal dengan SPEAKING. Dari pendapat-pendapat tersebut dapat disimpulkan bahwa konteks merupakan komponen yang penting dalam sebuah tuturan. Adanya konteks, mitra tutur dapat mengetahui dan dapat mengerti makna atau maksud yang ingin disampaikan oleh penutur.

Tindak tutur ilokusi ditampilkan melalui penekanan komunikatif suatu tuturan. Rohmadi (2004) mengungkapkan bahwa tindak ilokusi adalah tindak tutur yang berfungsi untuk mengatakan atau menginformasikan sesuatu dan dipergunakan untuk melakukan sesuatu, disebut juga the act of doing something. Tarigan (2009) "Tindak ilokusi adalah melakukan suatu tindakan dalam mengatakan sesuatu. Berdasarkan beberapa pendapat tersebut, dapat disimpulkan bahwa tindak tutur ilokusi adalah tindak tutur yang berfungsi untuk melakukan suatu tekanan dalam suatu tuturan yang pengindentifikasiannya harus didasarkan pada konteks saat tuturan tersebut dituturkan. 
Menurut Austin (dalam Lubis, 2011) mengatakan bahwa, "tindak ilokusi yaitu pengucapan suatu pernyataan, tawaran, janji pertanyaan, dan sebagainya." Pembagian tindak tutur berdasarkan maksud penutur ketika berbicara (ilokusi) dibagi dalam lima jenis (Putrayasa, 2014). Kelima tindak tutur tersebut adalah sebagai berikut.

a. Tindak tutur representatif atau asertif yaitu tindak tutur yang berfungsi untuk menetapkan atau menjelaskan sesuatu apa adanya. Tindak tutur ini seperti menyatakan, melaporkan, memberitahukan, menjelaskan, mempertahankan, menolak, dan lain-lain.

b. Tindak tutur komisif, yaitu tindak tutur yang berfungsi untuk mendorong pembicaran melakukan sesuatu, seperti berjanji, bernazar, bersumpah, dan ancaman.

c. Tindak tutur direktif yaitu, tindak tutur yang berfungsi untuk mendorong pendengar melakukan sesuatu, misalnya menyuruh, memerintah, dan meminta.

d. Tindak tutur ekspresif, tindak tutur ini berfungsi untuk mengekspresikan perasan, dan sikap. Tindak tutur ini berupa tindak tutur meminta maaf, berterima kasih, menyampaikan ucapan selamat, memuji, dan mengkritik.

e. Tindak tutur deklaratif, yaitu tindak tutur yang berfungsi untuk memantapkan sesuatu yang dinyatakan, antara lain dengan setuju, tidak setuju, benar-benar salah, dan sebagainya.

Istilah novel berasal dari Bahasa Latin yaitu "novellus" yang diturunkan dari kata "novies" yang berarti baru: cerita yang baru muncul kemudian sesudah drama, puisi, dan lain-lain (Tarigan dalam Zulfahnur, 1996). Nurgiyantoro (2013) mengemukakan bahwa novel adalah karya fiksi yang dibangun oleh unsur-unsur pembangun, yakni unsur instrinsik dan unsur ekstrinsik. Novel juga diartikan sebagai suatu karangan berbentuk prosa yang mengandung rangkaian cerita kehidupan seseorang dengan orang lain di sekelilingnya dengan menonjolkan watak dan sifat perilaku.

Berdasarkan pendapat tersebut dapat disimpulkan bahwa novel adalah suatu karya fiksi yang berisi rangkaian cerita bernilai esensial yang terinspirasi dari kehidupan nyata, dan selanjutnya diekspresikan dengan Bahasa yang estetis, novel sebagai suatu karya sastra memiliki daya pikat, dan kemampuan menarik minat publik terhadap karya sastra.

Dihubungkan dengan pendidikan penelitian ini dapat diimplementasikan pada Mata Pelajaran Bahasa Indonesia Kurikulum 2013 diimplementasikan pada jenjang Sekolah Menengah Pertama (SMP) kelas VIII semester genap dengan Kompetensi Dasar (KD) 3.14 Menelah struktur dan kebahasaan teks persuasi yang berupa saran, ajakan, arahan, dan pertimbangan tentang berbagai permasalahan aktual, dan Kompetensi Dasar (KD) 4.14 Menyajikan teks persuasi (saran, ajakan, arahan, dan pertimbangan) secara tulis, dan lisan dengan memperhatikan struktur, kebahasaan, atau aspek lisan.

Metode yang digunakan dalam penelitian ini adalah motode deskriptif. Metode deskriptif digunakan oleh penulis untuk memberikan gambaran mengenai keadan sebenarnya tentang tindak tindak tutur ilokusi asertif, direktif, ekspresif, komisif, dan deklarasi dalam novel guru Aini karya Andrea Hirata. 
Bentuk penelitian ini adalah kualitatif. Menurut Auerbach and Silverstein (dalam Arikunto, 2014) penelitian kualitatif merupakan penelitian yang dipakai untuk menganalisis, menginterpretasi teks, dan hasil interview yang bertujuan untuk menemukan makna dari suatu fenomena. Penelitian kualitatif merupakan bentuk penelitian yang menggambarkan suatu keadan dengan uraian.

Data yang digunakan dalam penelitian ini adalah semua kutipan yang menunjukkan tindak tutur ilokusi asertif, direktif, komisif, ekspresif, dan deklarasi yang terdapat dalam novel Guru Aini karya Andrea Hirata. Menurut Arikunto (2013) yang dimaksud data dengan sumber data penelitian adalah subjek dari mana data tersebut diperoleh. Sumber data dalam penelitian ini adalah sebuah novel.

$\begin{array}{ll}\text { 1. Judul Buku } & \text { : Guru Aini } \\ \text { 2. Penulis } & \text { : Andrea Hirata } \\ \text { 3. Kategori Buku } & \text { : Novel } \\ \text { 4. Penerbit } & : \text { Bentang Pustaka } \\ \text { 5. Tahun Terbit } & : 2020 \\ \text { 6. Cetakan } & : \text { Cetakan I, Februari 2020 } \\ \text { 7. ISBN } & : 978-602-291-686-4 \\ \text { 8. Tebal Buku } & : 336 \text { halaman } \\ \text { 9. Jenis Kertas } & : \text { Bookpaper } 55 \mathrm{gr} \\ \text { 10. Sampul Depan } & : \text { Art Carton } 230 \mathrm{gr} \\ \text { 11. Dimensi } & : 13 \times 21 \mathrm{~cm}\end{array}$

Teknik pengumpulan data yang digunakan dalam penelitian ini adalah teknik dokumenter. Teknik dokumenter (teknik studi pustaka), yaitu teknik pengumpulan data dan informasi melalui pencarian dan penemuan bukti-bukti. Teknik dokumenter ini merupakan teknik pengumpulan data yang berasal dari sumber non-manusia adalah teks atau informasi berupa dalam novel Guru Aini karya Andrea Hirata. Adapun langkahlangkah dalam penelitian ini sebagai berikut.

a. Membaca keseluruhan novel Guru Aini karya Andrea Hirata secara cermat, dan pemahaman tentang bentuk tindak tutur ilokusi.

b. Penulis mengindentifikasi data-data apa saja yang termasuk tindak tutur ilokusi asertif, direktif, ekspresif, komisif, dan deklarasi dalam novel Guru Aini karya Andrea Hirata.

c. Mengklasifikasikan data-data kedalam sebuah kelompok-kelompok yang termasuk tindak tutur direktif yang terdapat dalam novel Guru Aini karya Andrea Hirata.

d. Menganalisis data untuk dijadikan SPEAKING novel Guru Aini karya Andrea Hirata.

Alat pengumpulan data yang digunakan dalam penelitian ini adalah penulis, dalam instrumen kunci menggunakan SPEAKING. Kedudukan penulis sebagai instrumen kunci merupakan perencanan, pelaksanan, pengumpulan data, analisis, penafsiram data dan akhirnya menjadi pelapor hasil penelitian, untuk memperoleh data dan kata-kata maupun kalimat yang termasuk tindak tutur asertif, tindak tutur ilokusi, tindak tutur direktif, tindak tutur komisif, dan tindak tutur deklaratif.

Menguji keabsahan data perlu dilakukan agar data yang diperoleh benar- benar objektif, sehingga hasil penelitian ini dapat diperanggungjawabkan. Adapun teknik menguji keabsahan data yang dilakukan oleh penulis sebagai berikut. 


\section{Ketekunan Pengamatan}

Menurut Moleong (2014) ketekunan pengamatan bertujuan untuk menemukan ciri-ciri dan unsur-unsur dalam situasi yang sangat relevan dengan persoalan atau isu yang sedang dicari, kemudian memusatkan diri pada hal-hal tersebut secara rinci.

2. Kecukupan referensial dengan cara melengkapi teori yang berkaitan dengan penelitian serta menjadi landasan dalam mengabsahkan data.

Selajutnya penulis membaca, mengunjungi, dan menelaah sumber-sumber data serta berbagai pustaka yang relevan dengan masalah penelitian secara berulang-ulang. Sebelum menganalisis data langkah-langkah yang dilakukan penulis sebagai berikut

a. Penulis menganalisis data tindak tutur ilokusi asertif dengan menggunakan teknik analisis konteks.

b. Penulis menganalisis data tindak tutur ilokusi direktif dengan menggunakan teknik analasis konteks.

c. Penulis menganalisis data tindak tutur ilokusi komisif dengan menggunakan teknik analisis konteks.

d. Penulis menganalisis data tindak tutur ilokusi ekspresif dengan menggunakan teknik analisis konteks.

e. Penulis menganalisis data tindak tutur ilokusi deklarasi dengan menggunakan teknik analisis konteks.

f. Penulis menyimpulkan hasil penelitian yang telah dilakukan sehingga diperoleh deskripsi mengenai penggunan tindak tutur ilokusi asertif, direktif, komisif, ekspresif, dan deklarasi dalam novel Guru Aini.

\section{HASIL DAN PEMBAHASAN}

\section{ANALISIS TINDAK TUTUR ASERTIF}

1. Tuturan asertif menyatakan terdapat pada tuturan dengan kode data (AM/P2A/1), yaitu.

Ibu Amanah : "Mengapa kau sangat ingin menjadi guru matematika?"

Desi : "Sejak berjumpa dengan Bu Guru Marlis, kelas 3 SD dulu, aku sudah ingin menjadi guru matematika, Bu."

Ibu amanah : "Kau bisa dikirim ke pelosok, Desi, ke kampung yang listrik saja tak ada, aduh, seramnya! Kau tahu sendiri sumatra ni luas sekali, tak terhitung banyaknya pulau kecil, kau akan dipinggit nasib nanti diambil istri sama juragan kopra boleh jadi."

Desi : "Indonesia perlu guru matematika, Bu, apa boleh buat aku, aku siap bertugas di mana saja." Ibu Amanah : "Meski ke pulau terpencil"

Desi : "Siap, Bu."

Berdasarkan data di atas, tempat tindak tutur terjadi di sebuah rumah di satu kota kecil di tengah Pulau Sumatra, seperti dalam kutipan berikut.

"Pembicaran itu terjadi dalam sebuah rumah di satu kota kecil di tengah Pulau Sumatra sana"

Situasi santai tergambar dari data tersebut, karena peristiwa itu terjadi saat Ibu Amanah datag ke rumah Desi untuk mengetahui arah pendidikan Desi sela jurnya setelah lulus SMA. Partisipan yang mendukung tuturan adalah Desi Istiqomah sebagai penutur, dan Ibu Amanah sebagai mitra tutur. Tujuan Desi adalah menyatakan bahwa sejak bertemu Guru Marlis kelas 3 SD dulu penutur sudah ingin menjadi guru matematika.

2. Tuturan asertif memberitahukan terdapat pada tuturan dengan kode data $(\mathrm{AB} / \mathrm{P} 2 \mathrm{~A} / 20)$, yaitu. 
Ayah Desi : "Ini cara mengikat tali sepak bola, Desi, supaya tak lepas saat melakukan ten, dangan pisang!"

Desi : (Desi tahu ayahnya sangat sedih karena akan ditinggalkan anak perempuan satu-satunya).

Ayah Desi : "Nanti kau akan banyak turun naik kendaran, Nak, kalau tak kuat mengikat tali sepatu, bisa lepas sepatumu."

Desi : (Matanya berkaca-kaca)

Berdasarkan data di atas, tempat tindak tutur terjadi di depan rumah pada saat mEnunggu bus. Partisipan yang mendukung tuturan adalah ayah Desi sebagai penutur, ibu Desi, dan Desi sebagai mitra tutur.

3. Tuturan asertif menjelaskan terdapat pada tuturan dengan kode data $(\mathrm{AJ} / \mathrm{P} 5 \mathrm{~A} / 41)$, yaitu.

Aini : "Bu bagaimana tanda koma pada matematika

Bu Lusinun : "Tanda koma dipakai kalau kita ingin menulis angka Desimal,"

Aini : (mengagguk seolah menyemangati)

Berdasarkan data di atas tempat tindak tutur terjadi di sekolah. Partisipan yang mendukung tuturan tersebut adalah buk lusinun sebagai penutur, dan Aini sebagai mitra tutur. Tujuan penutur menuturkan tuturan tersebut bertujuan untuk menjelaskan kepada Aini bahwa tanda koma dipakai kalau kita ingin menulis angka Desimal.

4. Tuturan asertif mempertahankan terdapat pada tuturan dengan kode (AT/6PT/127), yaitu.

Bu Afifah : "Bu Desi yakin mau menerima, Aini?"

Bu Desi : "Sebenarnya kurang yakin, tapi apa salahnya mencoba. Kemauan anak itu sepertinya kuat sekali."

Bu Afiffah : "Guru akan menyesal"

Bu Desi : "Mengapa"

Bu Afifah : "Aku kenal Aini, Guru, nyanyi qasidah saja dia itu tak becus!"

Berdasarkan data di atas, tempat tindak tutur terjadi di sekolah. Partisipan yang mendukung tuturan tuturan adalah $\mathrm{Bu}$ Desi sebagai penutur, dan Bu Afifah sebagai mitra tutur. Tujuan penutur menuturkan tuturan tersebut bertujuan untuk mempertahankan kemauan muridnya Aini yang bernekad untuk masuk ke kelasnya.

5. Tuturan asertif menolak terdapat pada tuturan dengan kode data (AN/P6T/159), yaitu.

Bu Afifah : "Silakan Bapak mencari guru matematika lain untuk menggantikan kami." Kepala Sekolah : "Lantas Bu Afifah mau mengajar apa?"

Bu Afifah : "Aku mau kembali mengajar Bahasa Indonesia, Pak?

Berdasarkan data di atas, tempat tindak tutur terjadi di sekolah. Partisipan yang mendukung tuturan tersebut adalah $\mathrm{Bu}$ Afifahtur sebagai penur, dan Kepala Sekolah sebagai mitra tutrur. Tujuan penutur menuturkan tuturan tersebut bertujuan untuk menolok perminta n kepala sekolah untuk mengajar matematika, dan mau kembali mengajar Bahasa Indonesia.

\section{ANALISIS TINDAK TUTUR DIREKTIF}

1. Tuturan direktif meminta terdapat pada tuturan dengan kode (DI/P5B/7), yaitu.

Desi : (Bersedih karena tidak disetujui ibunya)

Ayah Desi : "Usah bersedih, Desi, kejarlah impianmu, nanti kalau melihat kau senang dengan mengajar, ibumu pasti mengerti,"

Desi : "Bersemangat sekali" 
Berdasarkan data di atas, tempat tindak tutur terjadi di rumah. Partisipan yang mendukung tuturan tersebut yaitu Ayah Desi sebagai penutur dan Desi sebagai mitra tutur. Tujuan Penutur menuturkan tuturan tersebut bertujuan untuk meminta Desi agar tidak bersedih, dan tetap melanjutkan cita-citanya untuk menjadi guru matematika.

2. Tuturan direktif memohon terdapat pada tuturan dengan kode data $(\mathrm{DO} / \mathrm{P} 7 \mathrm{~B} / 86)$, yaitu.

Enun : “Aini, usahlah kau pindah ke kelas Guru Desi. Usahlah kau tinggalkan grup trio kita. Aku punya lagu baru yang bisa kita tampilkan, Boi!"

Aini : "Lagu apa, Nun?"

Enun : "Lagu yang sip, Boi! Judulnya sudah Tenang di Alam Baku"

Berdasarkan data tersebut, tempat tindak tutur tersebut terjadi di sekolah. Partisipan yang mendukug tuturan tersebut adalah Enun sebagai penutur, dan Aini sebagai mitra tutur, Tujun Penutur menuturkan tuturan tersebut bertujuan untuk meminta Aini untuk tidak meninggalkan grub Trio Aljabaria.

3. Tuturan direktif mengajak terdapat pada tuturan dengan kode (DA/P7B/186), yaitu.

Bu Desi : "Maafkan aku kemarin, Boy"

Aini : "Tak perlulah Ibu minta maaf, akulah yang harus meminta maaf karena aku bodoh sekali."

Bu Desi : "Kau tak jengkel padaku, Nong?"

Aini : "Ah, sedikit pun tidak, Bu."

Bu Desi : "Nanti sore kutunggu kau, Nong, aku punya ide baru untukmu!"

Aini : "Tak sabar aku menunggu sore, Bu!"

Berdasarkan data di atas, tempat tuturan tersebut terjadi di depan rumah dinasGuru Desi. Partisipan yang mendukung tuturan tersebut adalah Guru Desi sebagai penutur, dan Aini sebagai mitra tutur. Tujuan penutur menuturkan tuturan tersebut bertujuan untuk mengajak Aini untu datang ke rumah Guru Desi karena ada perihal yang mau dibicarakan kepada Aini.

4. Tuturan direktif bertanya terdapat pada tuturan dengan kode data (DT/P2T/15), yaitu.

Bung Din : "Apakah ada sepatu khusus untuk anak perempuan yang akan mengajar mengajar matematika di daerah pelosok, Bung Zan?"

Bung Zan : "Berarti si sulung sudah lulus kuliah, Bung Din?

Bung Din : "Alhamdulillah, Bung Zan."

Berdasarkan data tersebut, tempat tuturan tersebut terjadi di kaki lima. Partisipan yang mendukung tuturan tersebut Bung Din sebagai penutur, dan Bung Zan sebagai mitra tutur.Tujuan penutur menuturkan tuturan tersebut bertujuan untuk menanyakan sepatu kepada temannya yang berjualan di kaki lima untuk anaknya yang akan mengajar di daerah pelosok.

5. Tuturan direktif memerintah terdapat pada tuturan dengan kode data (DM/P2A/9), yaitu.

Ibu Rektor : "Jangan dibuka sebelum aku keluar dari ruangan ini. Jantungku tak kuat mendengar teriakan-terikan kalian!"

Para lulusan matematika : (Para lulusan terlelak dalam tegang)

Berdasarkan data tersebut, tempat tindak tutur terjadi di ruang kelulusan. Partisipan yang mendukung tuturan tersebut adalah Ibu Rektor sebagai penutur, dan para lulusan matematika. Tujuan penutur menuturkan tuturan tersebut bertujuan untuk memerintah para lulusan matematika agar tidak membuka kertas penempatan kerja mereka. 
6. Tuturan direktif menyarankan terdapat pada tutran dengan kode data (DY/P8B/233), yaitu.

Debut : "Diskon buku terbesar yang pernah ada di dunia ini, hanya untuk guru Desi!"

Guru Desi : "Terima asih, But, tapi dari potonganmu nampak benar aku lebih punya duit ketimbang kau, usah macam-macam kau But."

Debut : "500 ribu?"

Guru Desi : "Ya, ambilah, aku malah tak tega membeli buku-buku ini dengan harga sangat murah"

Debut : (Debut berusaha menolak)

Guru Desi : "Cari lagi buku bagus-bagus, But! Nanti aku kembali."

Debut : (Debut terpana)

Berdasarkan data tersebut, tempat terjadinya tuturan tersebut terjadi di kios Debut. Partisipan yang mendukung tuturan tersebut adalah Guru Desi sebagai penutur, dan Debut sebagai mitra tutur. Tujuan penutur menuturkan tuturan tersebut bertujuan untuk menyarankan kepada Debut untuk mencari buku-buku yang lain karena suatu saat nanti Guru Desi akan kembali lagi untuk membeli buku.

\section{ANALISIS TINDAK TUTUR ILOKUSI EKSPRESIF}

1. Tuturan ekspresif meminta maaf terdapat pada tuturan dengan kode data (EM/P2A/160), yaitu.

Kepala Sekolah : "Maaf, kita tak bisa keluar dari garis besar haluan negara. Itu kewajiban konstitusional kita sebagai guru, sebagai warga negara Republik Indonesia."

$\mathrm{Bu}$ Afifah : "Usah sembarang bicara, Pak! Garis besar haluan negara tak ada bicara soal matematika!"

Kepala Sekolah : "Ada, ada, jangan salah, ada, garis besar haluan negara bicara tentang mencerdaskan kehidupan bangsa. Coba bayangkan apa jadinya kalau guru-guru matematika ganti profesi? Atau mau mengajar bi, dang studi lain? Jahiliah, jahiliah dalam kebodohan jadinya bangsa ini."

Bu Afifah : "Tidak bisa begitu, Pak!"

Berdasarkan data tersebut, tempat tejadinya tuturan di sekolah. Partisipan yang mendukung tuturan tersebut adalah Kepala Sekolah sebagai penutur, dan $\mathrm{Bu}$ Afifah sebagai mitra tutur. Tujuan penutur menuturkan tuturan tersebut yaitu Kepala Sekolah mengucapkan kata maaf karena tidak setuju dengan beberapa pendapat dari guru-guru tentang matematika.

2. Tuturan ekspresif berterima kasih terdapat pada tuturan dengan kode data (EB/P4T/192), yaitu.

Bu Desi : "Eyah kau dari hadapanku sekarang juga!"

Aini : "Terima kasih, Bu, sudah muntab padaku kemarin. Kalau Ibu tak muntab, takkan pernah mengerti aku arti kata limit!"

Bu Desi : (Menutup wajahnya dengan tangan)

Berdasarkan data di atas, tempat terjadinya tuturan tersebut terjadi di rumah Dinas Guru Desi. Partisipan yang mendukung tuturan tersebut adalah Bu Desi sebagai penutur, dan Aini sebagai mitra tutur. Tujuan penutur menuturkan tuturan tersebut yaitu Aini mengucapkan terima kasih kepada Bu Desi yang telah mungtap karena kalau tidak seperti itu Aini tidak akan pernah paham arti kata limit tersebut.

3. Tuturan ekspresif ucapan selamat terdapat pada tuturan dengan kode data (EU/P10B/149), yaitu.

Bu Desi : "Selamat, Nong, akhirnya kau terbebas dari kutukan bilangan biner!"

Aini : "Jadi... jadi aku bisa tetap di kelas Ibu?" 
Bu Desi : "Tangan mencincang, bahu memikul, sudah kukatakan padamu, aku hanya akan mengembalikanmu ke kelas Guru Tabah kalau nilai ulanganmu 0 atau 1"

Aini : "Mata Aini berkakaca-kaca.

Berdasarkan data tersebut, tempat terjadinya tutran tersebut terjadi di sekolah. Partisipan yang mendukung tuturan tersebut adalah Bu Desi sebagai penutur, dan Aini sebagai mitra tutur. Tujuan penutur menuturkan tuturan tersebut yaitu Bu Desi mengucapkan selamat kepada Aini karena Aini sudah mengerti sedikit strategi mengerjakan matematika, dan terbebas dari kutukan biner.

4. Tuturan ekspresif memuji terdapat pada tuturan dengan kode data $(\mathrm{EJ} / \mathrm{P} 1 \mathrm{~A} / 2)$, yaitu.

Bu Amanah : "Tengoklah dirimu, Desi, semampai, ramping, peringkat satu di sekolah, juara renang, cantik bukan buatan. Kalau kuliah di Jakarta, kau bisa sekalian menjadi model busana muslimah, sedang digemari sekarang. Bisa pula menjadi atlet renang."

Desi : "Tak bermintat menjadi model, Bu. Negeri ini kekurangan guru matematika, Bu, terutama di kampung-kampung."

Bu Amanah : "Idealis"

Berdasarkan data tersebut, tempat terjadinya tuturan tersebut terjadi di rumah Desi Istiqomah. Partisipan yang mendukung tuturan tersebutt adalah $\mathrm{Bu}$ Amanah sebagai penutur dan Desi Istiqomah sebagai mitra tutr. Tujuan penutur menuturkan tuturan tersebut yaitu Bu Amanah memuji kecantikan fisik Desi Istiqomah yang sangat sempurna dengan ba, dan semampai, ramping, peringkat satu di sekolah, juara renang, cantik bukan buatan bahkan bisa kuliah sambil menjadi model muslimah.

5. Tuturan ekspresif mengkritik terdapat pada tuturan dengan kode data (EG/P4T/170), yaitu.

Ibu Desi : "Itu pelajaran anak kelas 2 SMP! Mengapa kau taik bisa mengerjakannya?"

Aini : "Maaf aku lupa, Bu!"

Bu Desi : "Mengajarimu matematika macam mengajari ayam mengeong!"

Aini : (Aini tepekur dalam kalut, dan putus asa)

Berdasarkan data tersebut, tempat terjadinya tuturan tersebut terjadi di rumah dinas Guru. Partisipan yang mendukung tuturan tersebut adalah Desi.Bu Desi sebagai penutur, dan Aini sebagai mitra tutur. Tujuan penutur menuturkan tuturan tersebut yaitu Bu Desi yang kesal dengan tingkah Aini karena tidak ada peningkatan dalam belajar matematika.

\section{ANALISIS TINDAK TUTUR ILOKUSI KOMISIF}

1. Tuturan komisif berjanji terdapat pada tuturan dengan kode data $(\mathrm{KJ} / \mathrm{P} 8 \mathrm{~B} / 273)$, yaitu.

Aini : "Aku akan pulang sebagai dokter, Guru Desi, itu janjiku,"

Guru Desi : "Bawa buku ini, buku ini dulu kawan baikku"

Aini : (Aini melangkah untu naik bus itu)

Berdasarkan data tersebut, tempat terjadinya tuturan tersebut terjadi di depan gang rumah Aini. Partisipan yang mendukung tuturan tersebut adalah Aini, dan Guru Desi. Tujuan penutur menuturkan tuturan tersebut yaitu Aini akan berjanji kepada guru Desi suatu saat dia akan pulang telah menjadi dokter.

2. Tuturan komisif bersumpah terdapat pada tuturan dengan kode data $(\mathrm{KS} / \mathrm{P} 4 \mathrm{~B} / 15)$, yaitu. 
Bung Din : “Apakah ada sepatu khusus untuk anak perempuan yang akan mengajar matematika di daerah pelosok, Bung Zan?"

Bung Zan : "Berarti si sulung sudah lulus kuliah, Bung Din?"

Bung Din : "Alhamdulillah, Bung Zan. Tadi siang anakku sudah mengangkat sumpah jabatannya.

Merinding aku mendengar sumpah itu, Bung Zan. Betapa besar amanah yang harus ditanggung

pegawai negara. Beruntunglah kita hanya menjadi pedagang beras, dan pedagang sepatu"

Berdasarkan data di atas, tempat terjadinya tuturan terjadi di kaki lima, partisipan yang mendukung tuturan tersebut adalah Bung Din sebagai penutur, dan Bung Zan sebagai mitra tutur. Tujuan penutur menuturkan tuturan tersebut yaitu Bung Din memberitahukan kepada Bung Zan bahwa anaknya telah mengangkat sumpah jabatannya sebagai seorang pegawai.

3. Tuturan komisif ancaman terdapat pada tuturan dengan kode data (KA/P4T/130), yaitu.

Djumiantun : "Mungkin kalau kau putar-putar bolamu, otakmu, bisa ikut berputar, Aini."

Guru Desi : "Kalau kalian tak mengubah mental, meskipun Archimedes yang mengajari kalian matematika, kalian tetap takkan bisa!"

Aini, dan Djumiatun : (Aini, dan Djumiatun duduk diam di kelas untuk menenangkan diri)

Berdasarkan data tersebut, tempat terjadinya tuturan di sekolah. Partisipan yang mendukung tuturan tersebut adalah Guru Desi sebagai penutur, dan Aini serta Djumiatun sebagai mitra tutur. Tujuan penutur menuturkan tuturan tersebut yaitu Bu Desi mengancam Aini, dan Djumiatun ketika mereka berdua yang mengubah dirinya sendiri untuk belajar matematika Archimedes pun tidak akan bisa mengajarinya.

\section{ANALISIS TINDAK TUTUR ILOKUSI DEKRALASI}

1. Tuturan dekralasi setuju terdapat pada tuturan dengan kode data (DS/P2A/86), yaitu:

Enun : "Aini usah risau, Boi! Aku mendukungmu pindah ke kelas Bu Desi! Seratus persen kudukung! Sekolah lebih penting dari grub vokal!"

Aini : "lagu apa, Nun?"

Enun : "Lagu yang sip, Boi! Judulnya Sudah Tenang di Alam Baka."

Berdasarkan data di atas, tempat terjadinya tuturan terjadi di sekolah. Partisipan yang mendukung tuturan tersebut adalah Enun sebagai penutur, dan Aini sebagai mitra tutur. Tujuan penutur menuturkan tuturan tersebut yaitu Enun mendukung Aini untuk pindah ke kelas Bu Desi karena menurut Enun sekolah lebih penting dari grub vokal mereka.

2. Tuturan dekralasi tidak setuju terdapat pada tuturan dengan kode data (DT/P3T/3), yaitu.

Rudiansyah : "Kita bisa sama-sama kuliah di Me, dan, Desi, kita bisa selalu bersama nant!"

Desi : "Kita?! Bagaimana dengan orang lain?! Bagaimana dengan pengabdian?!"

Rudiansyah : "Kau yakin mau menjadi guru, Desi?"

Desi : "Itu bicara yang tak pantas!"

Berdasarkan data tersebut, tempat terjadinya tuturan terjadi di perpustakan. Partisipan yang mendukung tuturan tersebut adalah Desi sebagai penutur, dan Runding sebagai mitra tutur. Tujuan penutur menuturkan tuturan tersebut yaitu Desi tidak menyetujui saran Runding untuk kuliah di Me, dan karena menurut runding nasib seorang guru memprihatinkan.

3. Tuturan dekralasi benar-benar salah terdapat pada tuturan dengan kode data (DB/P15B/124), yaitu. 
Desi : "Laila, apakah kemarin aku menyebut nama anak itu padamu?"

Laila : "Tidak"

Desi : "Aduh siapa ya nama anak itu?Nani, Rini...”

Laila : "Marni!"

Desi : "Bukan, bukan Marni, Dini, Lani..."

Laila : "Murni"

Desi : "Bukan, Sani, Arni..."

Berdasarkan data tersebut, tempat tejadinya tuturan di jalan saat diboncengi Laila. Partisipan yang mendukung tuturan tersebut adalah Desi sebagai penutur, dan Laila sebagai mitra tutur. Tujuan penutur menuturkan tuturan tersebut yaitu Desi menyalahkan Laila yang berusaha mengingat nama murid Desi yang telah pindah ke kelasnya.

Dari hasil analisis tersebut sudah dijabarkan dan dibahas berbagai bentuk tindak tutur di dalam novel yang diteliti. Penelitian tersebut dapat diimplementasikan dalam pembelajaran kurikulum 2013. Pengembangan kurikulum merupakan bagian dari strategi untuk meningkatkan pendidikan. Oleh karena itu, terdapat sejumlah faktor seperti lama siswa bersekolah, lama siswa bersekolah, lama siswa tinggak di sekolah, pembelajaran siswa aktif berbasis kompetensi, buku pegangan, dan peranan guru sebagai tenaga pengajar sangat mempengaruhi mutu pendidikan di Indonesia.

\section{PENUTUP}

Berdasarkan hasil analisis data terhadap dialog antara penutur dan mitra tutur yang terdapat di dalam novel Guru Aini, terdapat beberapa simpulan sebagai berikut.

1. Penulis menemukan 25 tindak tutur yang terdiri atas 7 tuturan menyatakan, 8 tuturan tuturan memberitahukan, 2 tuturan melaporkan, 5 tuturan menjelaskan, 1 tuturan mempertahankan 2 tuturan menolak. Oleh karena itu, dapat disimpulkan bahwa tuturan memberitahukan lebih dominan dalam tindak tutur ilokusi komisif yang terdapat pada dialog novel Guru Aini.

2. Penulis menemukan 35 tindak tutur direktif yang terdiri atas 7 tuturan meminta, 3 tuturan memohon, 2 tuturan mengajak, 15 tuturan bertanya, 7 tuturan memerintah, dan 1 tuturan menyarankan. Oleh karena itu, dapat disimpulkan bahwa tuturan bertanya lebih dominan dalam tindak tutur ilokusi direktif yang terdapat pada dialog novel Guru Aini.

3. Penulis menemukan 24 tindak tutur ekspresif yang terdiri atas 5 tuturan meminta maaf, 4 tuturan berterima kasih, 5 ucapan selamat, 9 ucapan memuji, dan 1 ucapan mengkritik. Oleh karena itu, dapat disimpulkan bahwa tuturan memuji lebih dominan dalam tindak tutur ilokusi ekspresif yang terdapat pada dialog novel Guru Aini.

4. Penulis menemukan 5 tindak tutur komisif yang terdiri atas 1 tuturan berjanji, 1 tuturan bersumpah, dan 3 tuturan ancaman sedangkan tuturan bernazar tidak ditemukan. Oleh karena itu, dapat disimpulkan bahwa tuturan ancaman lebih dominan dalam tindak tutur ilokusi komisif yang terdapat pada dialog novel Guru Aini.

5. Penulis menemukan 10 tindak tutur deklarasi yang terdiri atas 4 tuturan setuju, 4 tuturan tidak setuju, dan 2 tuturan benar-benar salah. 
6. Hasil analisis tindak tutur ilokusi dalam novel Guru Aini dapat digunakan dalam kegiatan pembelajaran di sekolah khususnya sebagai bahan ajar (teks pemodelan), dan media pembelajaran dalam materi pelajaran Bahasa Indonesia.

\section{REFERENSI}

Abdullah, Sani Ridwan. 2014. Pembelajaran saintifik untuk kurikulum 2013. Jakarta: Bumi Aksara.

Arikunto, Suharsini. 2013. Prosedur Penelitian Suatu Pendekatan Praktik. Jakarta: Pustaka Setia.

Avista, Nansi. 2013. "Tindak Tutur Ilokusi Percakapan Antartokoh dalam Novel Hujan Bulan Juni Karya Sapadi Djoko Damono. (SKRIPSI). Pontianak: FKIP.

Burhan, Nurgiyantoro. (2009). Penilaian Pengajaran Bahasa. Yogyakarta: BPFE.

Chaer, Abdul. (2013), Kajian Bahasa. Jakarta: Rineka Cipta.

Chear, Abdul dan Leonie Agustin. 2003. Sosiolinguistik Perkenalan Awal. Jakarta: Rineka Cipta.

Darma, Yoce Aliah. 2014. Analisis Wacana Kritis: dalam Multidisipliner. Bandung: Refika Aditama.

Dirman dan Juarsih, Cicih. 2014. Pengembangan Kurikulum. Jakarta:Rineka Cipta.

Fadhilah, Rizki. 2018. "Tindak Tutur Ilokusi dalam novel Annoying Boy karya Inesia Pratiwi" Skripsi. Pontianak: FKIP.

H.B. Sutopo. 2002. Metodologi Penelitian Kualitatif. Surakarta: UNS Press.

Hirata, Andrea. 2020. Guru Aini. Yogyakarta: Penerbit Bentang.

Hp, Achmad, Abdullah, Alek. 2012. Linguistik Umum. Jakarta: Erlangga.

Ibrahim, Abdul. Syukur. 1993. Kajian Tindak Tutur. Surabaya: Usaha Nasional.

Leech, Geoffrey. 1983. Prinsip-prinsip Pragmatik. Jakarta: Universitas Indonesia.

Leech, Geoffrey. 1993. Prinsip-prinsip Dasar Pragmatik. Jakarta: Rajawali Pers.

Leech, Geoffrey. 2011. Prinsip-prinsip Pragmatik. Jakarta: Universitas Indonesia.

Lubis, Hamid Hasan. 2011. Analisis Wacana Pragmatik: Medan: Angkasa.

Lubis, Hamid Hasan. 2015. Analisis Wacana Pragmatik: Medan: Angkasa.

Moleong, Lexy J. 2010. Metodologi Penelitian Kualitatif. Bandung: PT Remaja

Moleong, Lexy J. 2014. Metode Penelitian Kualitatif. Bandung: PT Remaja Rosdakarya.

Nadar, F. X. 2013. Pragmatik dan Penelitian Pragmatik. Yogyakarta: Graha Ilmu.

Nurgiyantoro, Burhan. 2013. Teori Pengkajian Fiksi. Yogyakarta: Gajah Mada University Press.

Parare, J. D. 2004. Teori Semantik: Jakarta: Erlangga.Pragmatik Surakarta: Yuma Pustaka.

Parare, Jos D. 1991. Kajian Linguistik Umum, History Komparatif, dan Tipologi Struktural edisi kedua. Jakarta: Erlangga

Putrayasa, Ida Bagus, 2014. Pragmatik. Cetakan pertama. Yogyakarta: Graha Ilmu.

Putrayasa, Ida Bagus. 2014. Pragmatik. Yogyakarta: Graha Ilmu.

Rahardi, Kunjana. 2006. Sosiopragmatik. Yogyakarta: Erlangga.

Rahardi, Kunjana. 2009. Sosiopragmatik. Yogyakarta: Erlangga.

Rohmadi, Muhammad. 2004. Pragmatik Teori dan Analisis. Surakarta: Yuma Pustaka.

Rohmadi, Muhammad. 2010. Analisis wacana Pragmatik. Surakarta: Yuma Pustaka.

Rohmadi, Muhammad. 2011. Pragmatik Teori dan Analisis. Sukarta: Yuma Pustaka.

Rohmadi, Muhammad. Khundaru Sadhono. Sri Hastuti. 2013. Kajian Pragmatik: Peran Konteks Sosial, dan Budaya dalam Tindak Tutur Bahasa di Pacitan. Surakarta: Yuma Pustaka.

Rusminto, Nurlaksana Eko. 2010. Analisis Wacana Sebuah Kajian Teoritis dan Praktis. Bandar. Lampung: Universitas Lampung.

Rusminto, Nurlaksana Eko. 2015. Analisis Wacana: Kajian Teoritis dan Praktis. Yogyakarta: Graha Ilmu.

Rustono, 1999. Pokok-pokok Pragmatik. Semarang: IKIP Semarang PRESS.

Sahlan, Asmaun dan Angga Teguh Prastyo. 2012. Desain Pembelajaran Berbasis Pendidikan Karakter. Jakarta: Ar Ruzz Media.

Sudaryanto. 1993. Metode dan Aneka Teknik Analisis Bahasa. Yogyakarta: Duta Wacana University Press.

Sugiyono, 2018. Metode penelitian kuantitatif, kualitatif dan campuran. Bandung. Alfabeta

Sumarsono. 2010. Sosiolinguistik. Yogyakarta: Pustaka Pelajar.

Tarigan, Henry Guntur. 2009. Pengajaran Pragmatik. Bandung: Angkasa.

Verhaar, J.W.M. 1996. Asas-asas Linguistik Umum. Yogyakarta: Gadjah Mada University Press. 
Wijana, 1 Dewa Putu dan Muhammad Rohmadi, 2011. Analisis Wacana Pragmatik KajianTeoro dan Analisis. Surakarta: Yuma Pustaka.

Yule, George. 1996. Pragmatik. Yogyakarta: Pustaka Pelajar.

Yule, George. 2006. Pragmatik. Yogyakarta: Pustaka Belajar.

Yule, George. 2015. Kajian Bahasa. Yogyakarta: Pustaka Pelajar.

Zulfahnur, dkk. 1996. Teori Sastra, Jakarta: Depdikbud. 